\title{
The Challenges and Effects of Policies Implemented in U.S. Under Covid-19
}

\author{
Xingzhi $\mathrm{Ma}^{1, *}$ \\ University of Miami, Economics Department, Coral Gables 33146, U.S. \\ *Corresponding author. Email: mikemaxingzhi@outlook.com
}

\begin{abstract}
Under the invasion of Corona Virus, known as covid-19, strict lockdown has been enforced as strongly in all other countries as in the U.S, in the primary purpose of countering any further dissemination. With such circumstances incurring severe economic crisis are the high unemployment rate and low liquidity, reaching an unprecedented level after the 2008 financial crisis. Though U.S. government has imposed fiscal and monetary remedies to save the economy, the result seems unsatisfactory. This paper will discuss which factors hinder the implemented remedies and how effective these polices are in the give period. With the quantitative model and statistical graph, the results extrapolated in the several latest researches show the effectiveness of monetary policies such as direct and indirect government transfer. In the model, it can be seen a decreasing trend of bankruptcy rate among small business and recovering stock market on graphs. From the policies analysis relative to market reaction, we conclude that these tools indeed, though inefficiently, help the economy in the scope of labor market and financial market.
\end{abstract}

Keywords: economic crisis; covid-19; employment; fiscal policy; monetary policy

\section{INTRODUCTION}

At the end of February 2020, Corona Virus, named as Covid-19 by WHO, began to outbreak in the United States. The unemployment rate in the US skyrocketed to around $15 \%$ after April. The annual inflation rate in may was $0.13 \%$ with an adjusted rate of $0.95 \%$, while in September, the official CPI was recorded a $1.41 \%$ inflation rate with an adjusted rate of $1.9 \%$ [1]. With the sudden decreasing economic growth and increasing unemployment rate in the first quarter, the United States government started to implement monetary, fiscal and other policies to stabilize the economy. On the monetary side, the unconventional monetary policy such as "quantitative easing", "forward guidance", "extended liquidity operations" and the "adjustment of interest rate" were mainly used to accelerate the liquidity and vitality of economy and to increase the demand. On the fiscal side, Trump's administration also used government transfers, such as unemployment insurance and economic impact payments, to help individuals and firms. However, the effects of policies seems faint. The US economy and the stock market was continued to fluctuate and began to bounce back in a slow rate.
With this unprecedented status, it may seems essential to discuss the severe situation and proper treatments with primary evaluation. The main purpose of this paper is to find out the effectiveness of policies and their preliminary achievements. On the application side, we will also draw a comprehensive image at the end about information of financial and labor market based on the policy implementation. In this paper, some challenges for police makers that impede the progress of policies implemented are addressed and summarized, for instance, the lack of liquidity between different sectors and the fail of stimulus because of the spending composition, and the policies implemented and their effects on the US economy are discussed. In particular, this paper will mainly focus on the CARES act, PPP and other fiscal policies and their effect on the recovery of the US economy.

This paper will compare and identify the policies and its implementing date corresponding to the reaction of market on a timeline. Graphs and data will be presented to show the influences of policies on other aspects such as the income and spending composition. For example, on the analysis of unemployment, statistical analysis model will be used to show the income composition and therefore to evaluate unemployment benefits. Similarly, simplified regression 
model of bankruptcy rate is used to find the relation between policies and market reaction on monthly scaled charts.

\section{THE US ECONOMY}

\subsection{The US economy before Covid-19}

Prior to the shutdown, the unemployment fell to $3.5 \%$ at the end of 2019, even less than the Fed's expectation. The unemployment was at a historical low level. The growth rate reached around $3 \%$ in 2020 before the covid-19. The economy was in a constant increasing trend and Fed expected even a higher growth rate in 2020 if covid-19 did not happened. The financial market was also reached a historical high point at the beginning of 2020 in the last three years starting from 2017 [2]

\subsection{The US economy under Covid-19}

The shutdown of economy brought considerable damages to the US economy. As the covid-19 began to spread out, the US GDP Q1 has a drop of 3\% and a drop of $9 \%$ in Q2. In the historical context, as shown in the Fig.1, the 2020 recession drove the economy down into a much deeper level comparing to the previous recession [3].

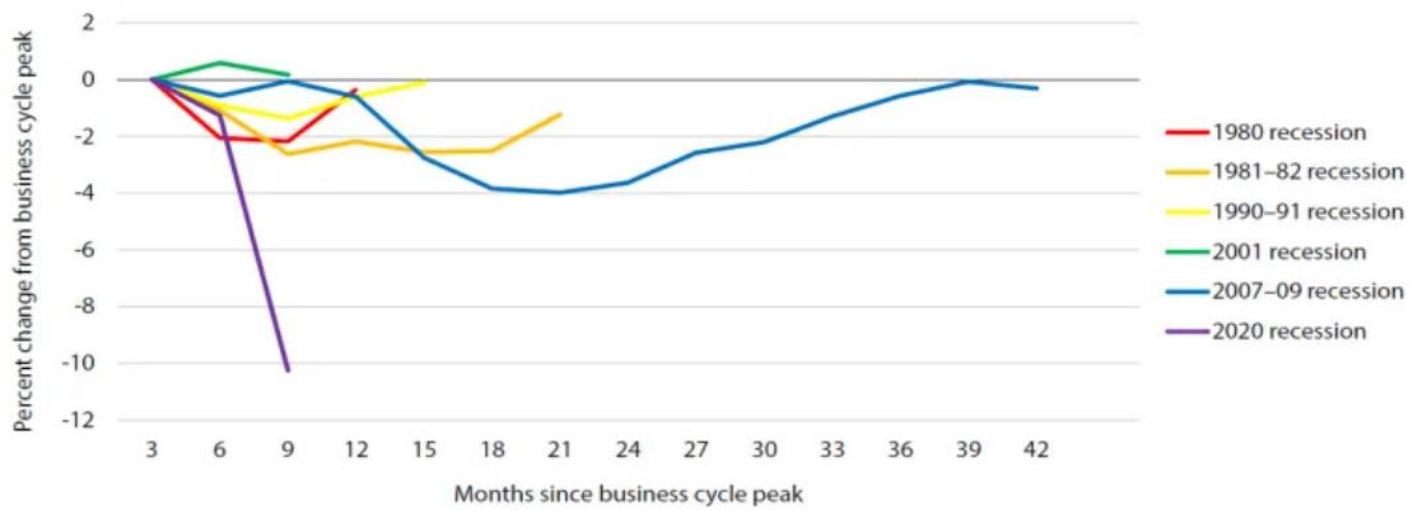

Figure 1 Percentage change in GDP relative to business cycle peak [4]

On the aspect of unemployment, the pandemic have a bigger impact in the labor markets than the several huge crisis before. The labor market turned to be inactive due to the close of major economic sectors especially services-intensive industries. Despite the sudden shock on the demand side of labor market, the recovery took place in a much faster rate comparing to the previous huge shocks. The high job finding rates and the indicated potential high job recall rate reactivate the vitality of labor market [5]. Data from CEA (Fig.2) show the escalated unemployment at which the rate reached a peak in April was as high as $14.7 \%$, signaling a dangerous warning to the economy.

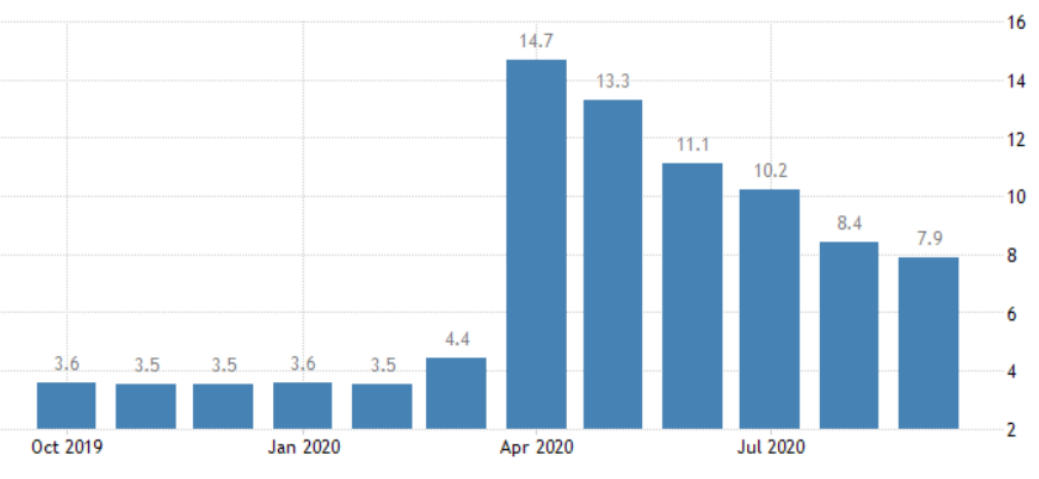

Figure 2 The US unemployment rate in Q1 \& Q2 [6]

The US stock market also seems bleak after the outbreak of pandemic and the enforcement of quarantine. The prices reached a peak from February 12 to February 19 and then drop dramatically over $37 \%$. There were numerous sudden crash and several circuit breaker took place between February to April.
Other economic sectors such food, retail and relevant services received the most severe shock under the pandemic. Recorded by the CEA, the occupancy rate of hotel and restaurant was halved. With the crisis occurred, the personal saving saw its highest, met a rate of $33 \%$ of the real disposable income. 


\section{CHALLENGES AND POLICIES IMPLEMENTATION}

\subsection{Challenges}

Different from the previous economic crisis, the stabilization tools are not working as well as before in pandemic. In the case of Covid-19, the transfer of payment between different economic sectors are imbalances. Some economics sectors are still operating under the pandemic while some sectors are closed, such as location based services. That some section has higher flow-out and some has higher flow-in in the current circular flow leads the inadequate provision of liquidity in the market. This will further lead to an allocative inefficiency. The cut in interest rate may not necessarily boost the economic activities in a way of spurring the demands, for an effective demand failure may have a boundary by the financial constrains. In this case, fiscal policies seems better than the monetary policies [7].

Another challenge is the measure of unemployment. It is crucial to construct a economic model for policy makers to forecast the future possible flow of labour market. In a latest research, the difference between the temporary unemployment and the permanent unemployment was considered in the model construction which later indicated that the temporary unemployed who are waiting for the recalling jobs may not influence the "tightness" of the labour market as the high job finding rate increased the supple of labour. The severity of unemployment was believed to be over-addressed due to the assumption on the outflow regarding to the experience of past recessions. Much harder it is to impose any further policies without a more precise prediction on the temporary unemployment as the job separation rate was took account in the predictive model [8]. The implementation of PPP also effected on the unemployment rate but in a complex way. Small firms with different sizes (from lower than 125 employees to more then 500 employees) reflect different economic reactions to the PPP [9].

In the case of Coivd-19, households' MPC was influenced by several major factors. The anticipation of future income and the policies that affects their income will play roles on their deposition decision. Thus, the real situation turns out to be a negative trend as a decline of economy was predicted though the CARES act was passed and impacted on the economy.

After a construction of a heterogeneous model, Luis et al. find that there are too many factors that have to be considered by the policy makers. Even though the researcher believes that much more works are needed in order to show the interrelationship between different factor, the result of the model at least gives a deeper insight about the overall status of the reaction to the stimulus such as the level of account balance and the level of cash hold in hand and the model also indicates that the reaction to stimulus was weaker in the high income group and in the high economic sectors than the lower sectors [10].

\subsection{Policies implementation}

According to the detailed research of IMF, the United States government under Trump administration imposed several important policy, both fiscal and monetary, to help to relief the contraction in the economy.

On the fiscal side, Trump issues several relief programs such as Disaster Relief Fund for Unemployment Benefits, Student Loan Relief, Paycheck Protection Program and Health Care Enhancement Act, deferring collections of employee social security payroll taxes, Coronavirus Aid, Relief and Economy Security Act (also known as CARES) etc. The CARES was estimated to have a size of US\$2.3 trillion, approximately $11 \%$ of the GDP, which designed to provide the bill for the basic safety of daily lives of individuals and families, while the Paycheck Protection Program, known as PPP, implemented at April 24, was designed to provide loans to small firms. Almost 4.9 million PPP loans have been approved to date, for a total of $\$ 518$ billion in PPP aid disbursed [9].

On the monetary policy side, according to the IMF, FED lowered the federal fund rate by $150 \mathrm{bp}$ in March to $0-0.25 \mathrm{bp}$. Other measures were applied to expand the overnight repurchase agreements and reduce the costs of swap agreements with other central banks as the foreign exchanges operations. Fed also supported the flow of credit and encouraged depository institutions to lend. The community bank leverage ratio was lowered to 8 percent according to IMF.

Beside the QE, Fed also use forward guidance, extended lending programs and other unconventional monetary tools. According to SPD and SPF, the forecasters were very optimistic about the economy, which makes the Fed believe that the forward guidance will continue providing the liquidity in markets and therefore help them to achieve their future economic goals [11].

\section{EFFECTS AND REACTIONS}

Even though, many evidences indicate that the policies implemented aimed to counter the crisis in this years play a weaker role comparing to the previous crisis, the stabilization policies such as fiscal stimulus plan did effect on the economy in a certain extent. The unconventional monetary policies were less efficient when dealing with economic difficulties in the case of covid-19. The forward guidance was much more tenuous than in settings with rational expectations and 
perfect credibility [11]. With an observation on the data on different macroeconomic aspects, the CARES act and PPP, the most "expensive" fiscal plan, were not efficient enough, yet push the economy to bounce back from further drop.

After the CARES act was enforced, data shows that the low income group response actively much stronger than expected. A drop in income and liquidity of payment results in the increase of MPC. In the Fig.3, we can see a decline of MPC with an increase of income. The income group of below $1 \mathrm{~K}$ has the highest MPC indicator of 5.6, and the income group of higher than $5 \mathrm{~K}$ has the lowest of around 3.
According to the Bureau of Economic Analysis, the CARES effect in several way at the early stage. The unemployment was slightly reduced from 14.7 to 13.3 after March. CARES act was believed to effect on income in a large extent. With the support of unemployment benefits, the disposable income level was elevated though a decline of consumption was observed. In Fig.4, we can see an increase in general consumption as social programs took placed from March to May [12]. however, it is still mainly driven by UI and EIP since the Disposable personal income experience a little decrease after March.

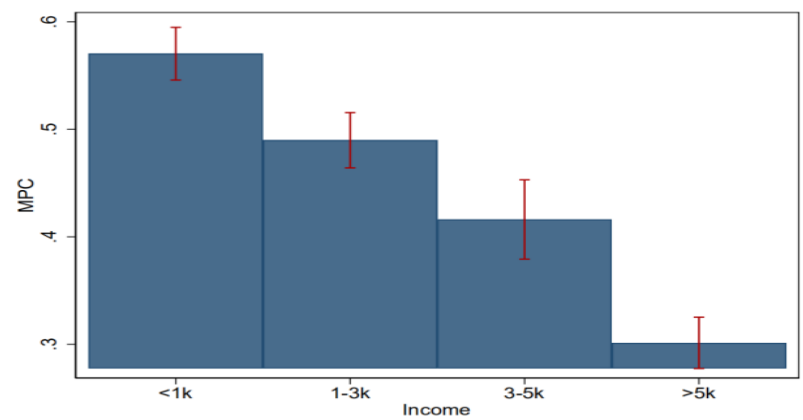

Figure 3 MPC by income group [12]

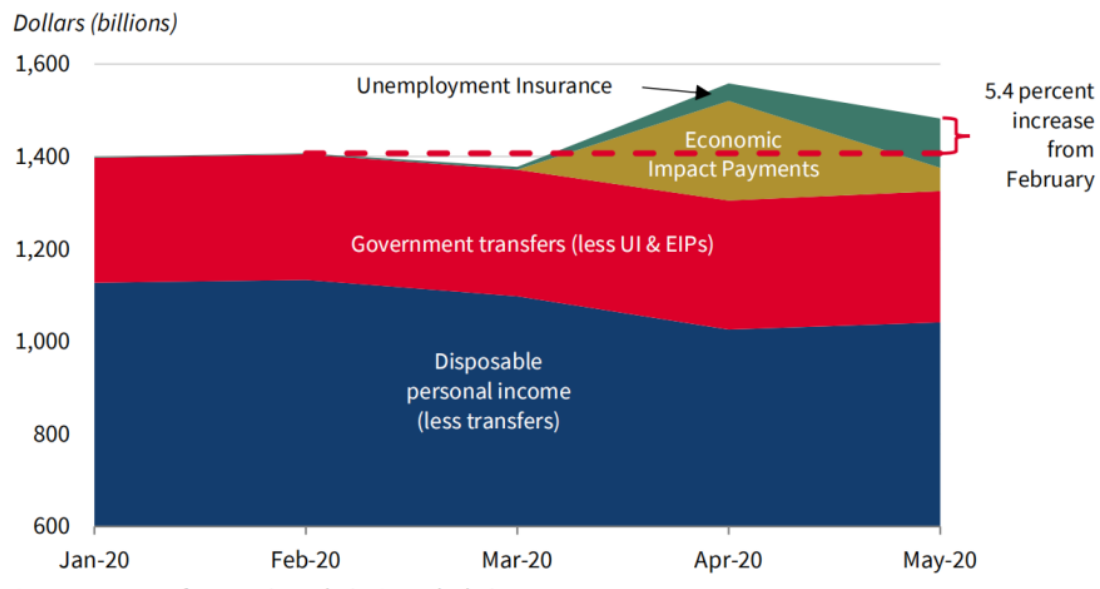

Sources: Bureau of Economic Analysis; CEA calculations.

Figure 4 Disposable income composition [4]

To assess the effect of CARES Act and PPP, we can also look up another indicator, which is the small business bankruptcies rate (specifically under Chapter 11). In the Fig.5, it can be observed that the bankruptcies have successfully being spiked. The overall filling rate has been declined in February and
March. In addition, the aggregate Chapter 7 bankruptcy filings, which refers to the liquidation of assets of small companies, have fallen by $13 \%$ from the period (October 2019 to July) comparing with the same period one year before [4]. 


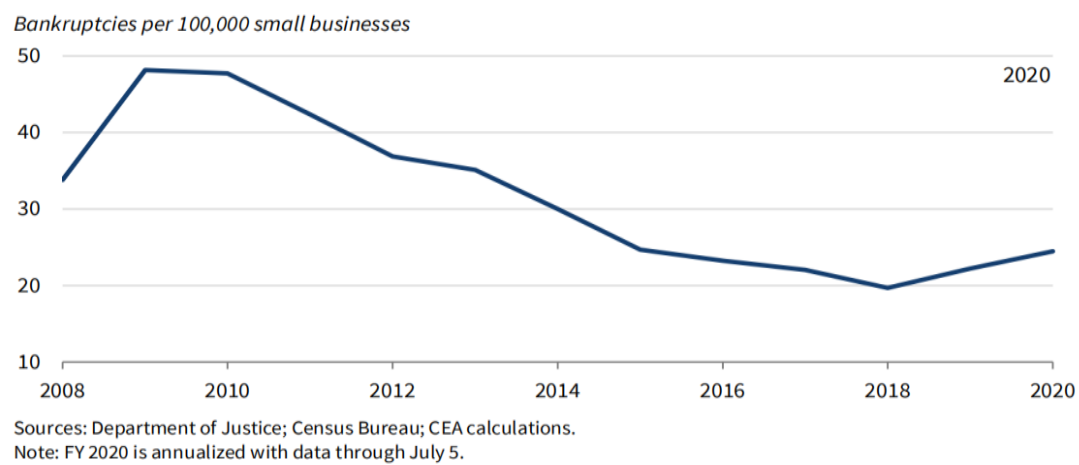

Figure 5 Bankruptcies per 100,000 small business [4]

Also according to the Council of Economic Advisers, based on the historical trend (Fig.6), the economy condition and PPP might be the cure to the Small Business bankruptcies. Beside the bankruptcies filling,

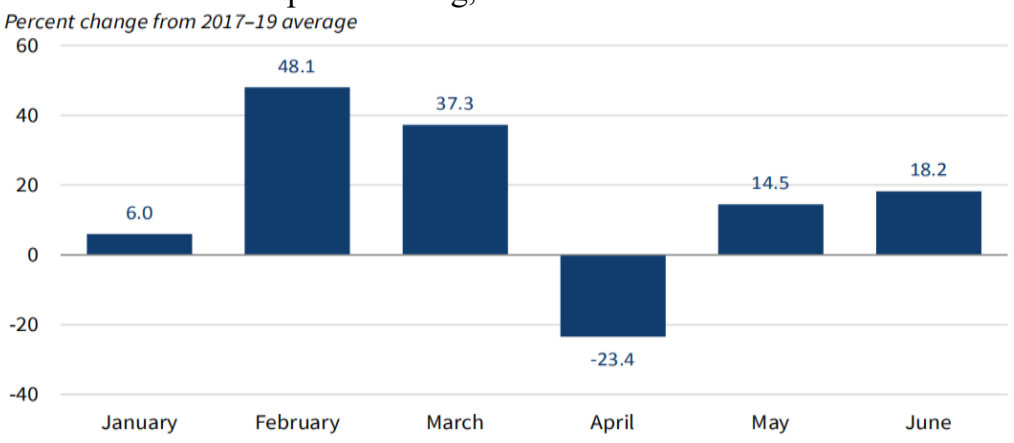

Sources: Department of Justice; CEA calculations.

Figure 6 Total Small Business U.S. Chapter 11 Bankruptcy Filings, 2020 [4]

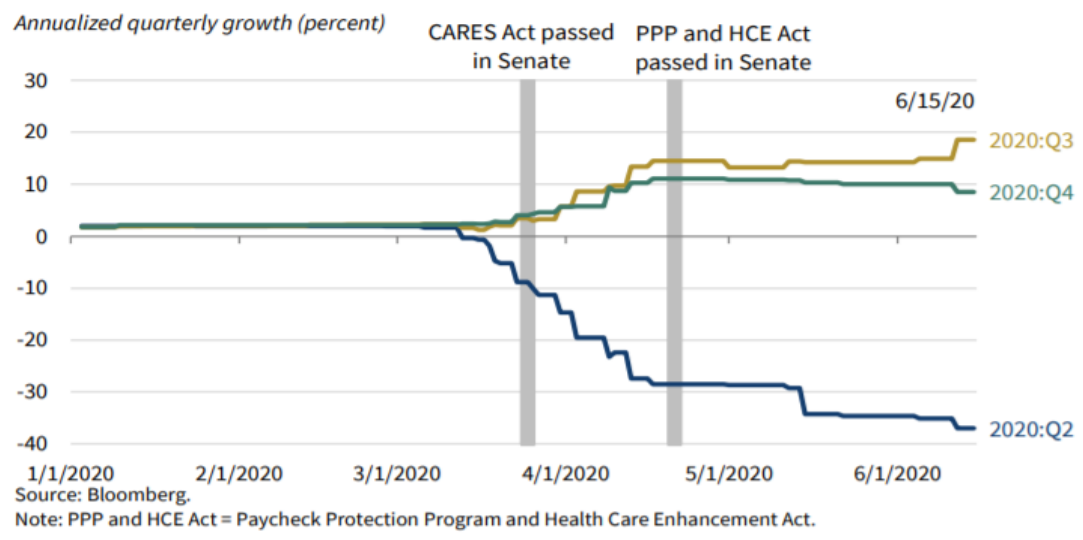

Figure 7 The US economy growth rate in Q1 \& Q2 [13]

The announcement of CARES act effects the confidence of financial market in a larger scale than in other economic sectors. In Fig.8, at the end of March, after a $37 \%$ decline in the first quarter, the S\&P index bounce back as the information of CARES act appeared on the media and began to slowly recover after entering other problems are exposed such as the loss of ability to acquire small loans and assets and the ability of reopening jobs. 


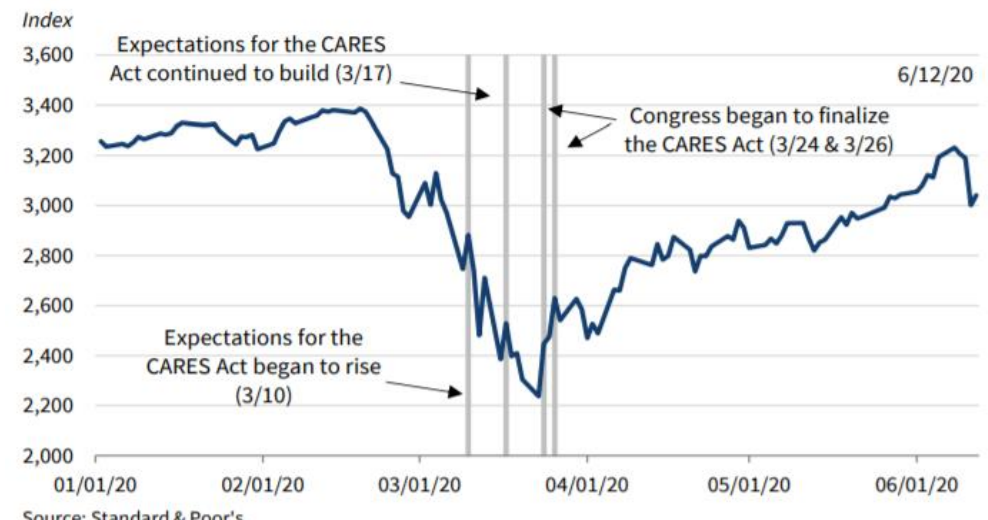

Figure 8 Effect of CARES Act to the Stock Market [13]
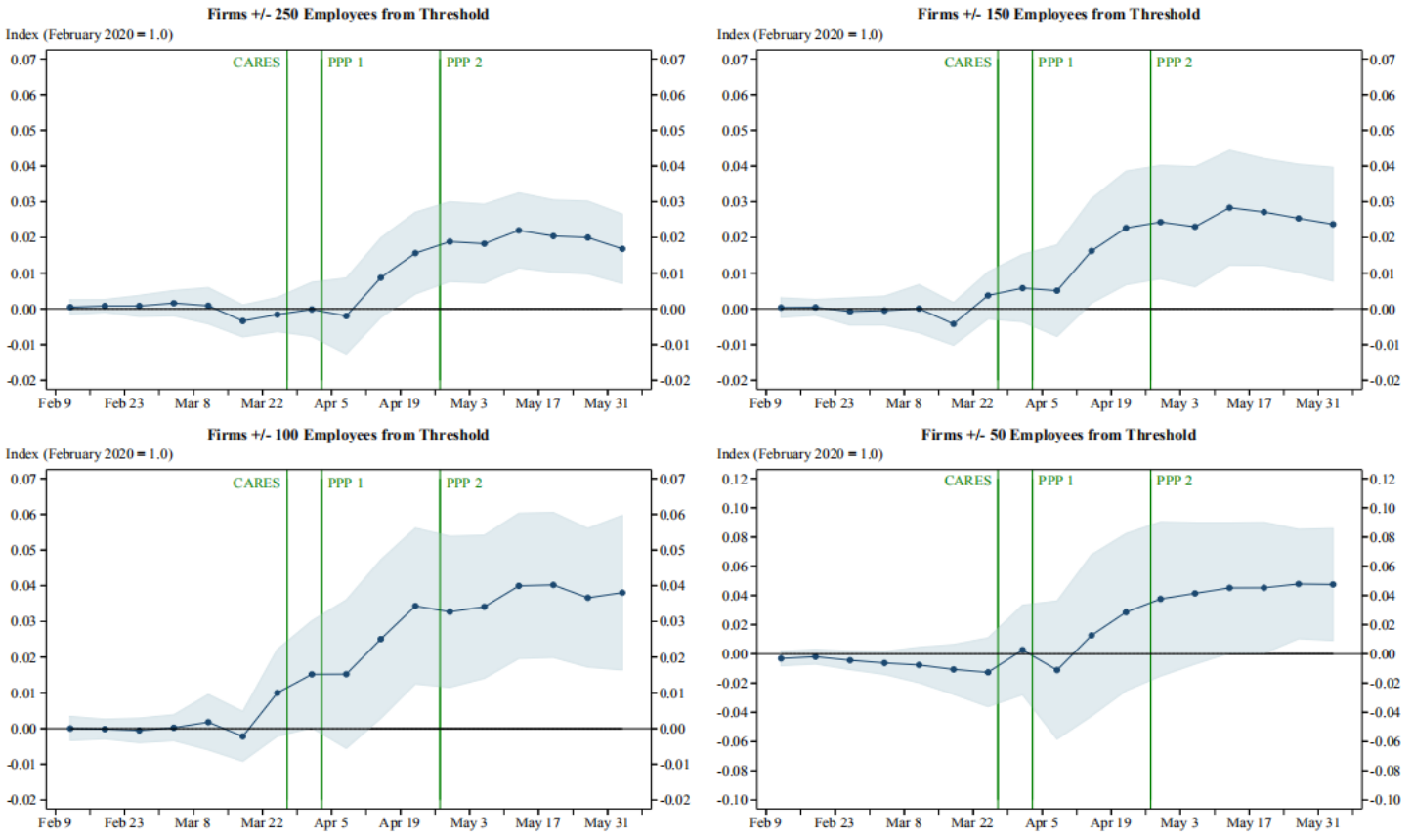

Figure 9 Effect of PPP Eligibility on Employment [9]

The latest research pointed out that high income countries announced larger monetary policy than lower income countries. The interest rates in high income countries become historically lowest comparing to previous crisis reaction. The result shows that the effects of monetary policy is largely limited by the country's access to credit markets [14]. This finding further approves the conclusions of which states the results of monetary policies under Covid-19 are unsatisfactory.

\section{CONCLUSION}

With series of discussion, it can be concluded that the Covid-19 was considerably challenging to the policy makers even in the historical context comparing with the previous recession. The skyrocketing unemployment rate and the falling financial market did not appear to be paused by the implemented policies. Although the effects of the policies did not reach the expectation, the unemployment rate and the stock market were successfully being controlled and stabled from further crashing. The challenges people might face have been identified when analyzing the economy, such as the lack of liquidity between different economic sectors and the inactive response to the stimulus, etc. We also found that the fiscal and monetary policies implemented by the US government did stabilized the economy for certain degree. The CARES Acts helped the household with their basic consumption and stimulate the aggregate demand. The PPP, on the other hands, helped small business to raise the employment rate and helped them to solve the financial difficulties.

This paper mainly aims to provide insights to policy makers, investors and market-engaged analyst, rather than constructive conclusion, due to the lack of precised model. It might also have significance as a policy analysis for those who study labor market and financial market. But if more constructive quantitative analysis are available, we might able to draw a comprehensive conclusion about the effective of policies. 


\section{AUTHORS' CONTRIBUTIONS} Ma.

This paper is independently completed by Xingzhi

\section{ACKNOWLEDGMENTS}

Special thanks to Professor. Stanimir Georgiev Morfov for helping me on finding the data and organizing the materials.

\section{REFERENCES}

[1] Barone, E. The Pandemic Is Costing Americans More Money Than Official Numbers Suggest. Retrieved November 30, 2020. https://time.com/5905902/covid-19-inflation/

[2] WSJ Noted. What Happened to the Economy Under Trump Before Covid and After, October 14, 2020. https://www.wsj.com/articles/what-happened-to-th e-economy-under-trump-before-covid-and-after-11 602713077

[3] Bauer, L., Broady, K., Edelberg,, W., \& O’Donnell, J. Ten Facts about COVID-19 and the U.S. Economy. Washington, DC, Massachusetts: The Hamilton, 2020, pp. 2-5.

[4] The Council of Economic Advisers, Evaluating The Effects Of The Economic Response To COVID-19. Washington D.C.: The Council of Economic Advisers, 2020.

[5] Hall, R. and Kudlyak, M., UNEMPLOYED WITH JOBS AND WITHOUT JOBS. [online] Cambridge, MA 02138: NATIONAL BUREAU OF ECONOMIC RESEARCH, 2020. <http://www.nber.org/papers/w27886>.

[6] Bureau of Economic Analysis. U.S. Bureau of Economic Analysis (BEA). https://www.bea.gov/.

[7] Woodford, M., EFFECTIVE DEMAND FAILURES AND THE LIMITS OF MONETARY STABILIZATION POLICY. [online] Cambridge, MA 02138: NATIONAL BUREAU OF ECONOMIC RESEARCH, 2020. <http://www.nber.org/papers/w27768>.

[8] Gallant, J., Kroft, K., Lange, F. and Notowidigdo, M., TEMPORARY UNEMPLOYMENT AND LABOR MARKET DYNAMICS DURING THE COVID-19 RECESSION. [online] Cambridge, MA 02138: NATIONAL BUREAU OF ECONOMIC RESEARCH, 2020. <http://www.nber.org/papers/w27924>.

[9] Autor, D. An Evaluation of the Paycheck Protection Program Using Administrative Payroll Microdata.
Massachusetts: MIT Department of Economics, 2020, pp. 8-9.

[10] Céspedes, L., Chang, R. and Velasco, A., THE MACROECONOMICS OF A PANDEMIC: A MINIMALIST MODEL. NBER WORKING PAPER SERIES. [online] Cambridge, MA 02138: NATIONAL BUREAU OF ECONOMIC RESEARCH, 2020. <http://www.nber.org/papers/w27228>.

[11] Levin, A., \&amp; Sinha, A. LIMITATIONS ON THE EFFECTIVENESS OF MONETARY POLICY FORWARD GUIDANCE IN THE CONTEXT OF THE COVID-19 PANDEMIC (Working paper No. 27748). 1050 Massachusetts Avenue Cambridge, MA: NATIONAL BUREAU OF ECONOMIC RESEARCH, 2020.

[12] Baker, S., Farrokhnia, R., Meyer, S., Pagel, M. and Yannelis, C., Income, Liquidity, And The Consumption Response To The 2020 Economic Stimulus Payments. NBER Working Paper No. 27097. NATIONAL BUREAU OF ECONOMIC RESEARCH, 2020.

[13] Executive Office of the President of the United States, CEA, Evaluating the effects of the economic response to covid-19, 2020. https://trumpwhitehouse.archives.gov /wp-content/uploads/2020/08/Evaluating-the-Effect s-of-the-Economic-Response-to-COVID-19.pdf

[14] Eichenbaum, M., Rebelo, S. and Trabandt, M., THE MACROECONOMICS OF EPIDEMICS. [online] Cambridge, MA 02138: NATIONAL BUREAU OF ECONOMIC RESEARCH, 2020. <http://www.nber.org/papers/w26882>. 